\title{
A sub-canopy structure for simulating oil palm in the Community Land Model (CLM-Palm): phenology, allocation and yield
}

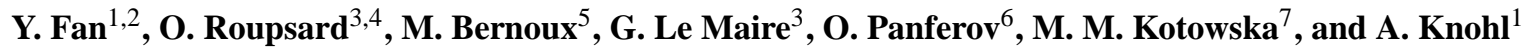 \\ ${ }^{1}$ University of Göttingen, Department of Bioclimatology, Büsgenweg 2, 37077 Göttingen, Germany \\ ${ }^{2}$ AgroParisTech, SIBAGHE (Systèmes intégrés en Biologie, Agronomie, Géosciences, Hydrosciences et Environnement), \\ 34093 Montpellier, France \\ ${ }^{3}$ CIRAD, UMR Eco\&Sols (Ecologie Fonctionnelle \& Biogéochimie des Sols et des Agro-écosystèmes), \\ 34060 Montpellier, France \\ ${ }^{4}$ CATIE (Tropical Agricultural Centre for Research and Higher Education), 7170 Turrialba, Costa Rica \\ ${ }^{5}$ IRD, UMR Eco\&Sols, 34060 Montpellier, France \\ ${ }^{6}$ University of Applied Sciences Bingen, 55411 Bingen am Rhein, Germany \\ ${ }^{7}$ University of Göttingen, Department of Plant Ecology and Ecosystems Research, Untere Karspüle 2, \\ 37073 Göttingen, Germany
}

Correspondence to: Y. Fan (yfan1@uni-goettingen.de)

Received: 15 May 2015 - Published in Geosci. Model Dev. Discuss.: 19 June 2015

Revised: 6 November 2015 - Accepted: 9 November 2015 - Published: 26 November 2015

\begin{abstract}
In order to quantify the effects of forests to oil palm conversion occurring in the tropics on land-atmosphere carbon, water and energy fluxes, we develop a new perennial crop sub-model CLM-Palm for simulating a palm plant functional type (PFT) within the framework of the Community Land Model (CLM4.5). CLM-Palm is tested here on oil palm only but is meant of generic interest for other palm crops (e.g., coconut). The oil palm has monopodial morphology and sequential phenology of around 40 stacked phytomers, each carrying a large leaf and a fruit bunch, forming a multilayer canopy. A sub-canopy phenological and physiological parameterization is thus introduced so that each phytomer has its own prognostic leaf growth and fruit yield capacity but with shared stem and root components. Phenology and carbon and nitrogen allocation operate on the different phytomers in parallel but at unsynchronized steps, separated by a thermal period. An important phenological phase is identified for the oil palm - the storage growth period of bud and "spear" leaves which are photosynthetically inactive before expansion. Agricultural practices such as transplanting, fertilization and leaf pruning are represented. Parameters introduced for the oil palm were calibrated and validated with field measurements of leaf area index (LAI), yield and net primary production (NPP) from Sumatra, Indonesia. In cal-
\end{abstract}

ibration with a mature oil palm plantation, the cumulative yields from 2005 to 2014 matched notably well between simulation and observation (mean percentage error $=3 \%$ ). Simulated inter-annual dynamics of PFT-level and phytomerlevel LAI were both within the range of field measurements. Validation from eight independent oil palm sites shows the ability of the model to adequately predict the average leaf growth and fruit yield across sites and sufficiently represent the significant nitrogen- and age-related site-to-site variability in NPP and yield. Results also indicate that seasonal dynamics of yield and remaining small-scale site-to-site variability of NPP are driven by processes not yet implemented in the model or reflected in the input data. The new subcanopy structure and phenology and allocation functions in CLM-Palm allow exploring the effects of tropical land-use change, from natural ecosystems to oil palm plantations, on carbon, water and energy cycles and regional climate.

\section{Introduction}

Land-use changes in Southeast Asia have been accelerated by economy-driven expansion of oil palm (Elaeis guineensis) agriculture since the 1990s (Miettinen et al., 2011). Oil 
palm is currently one of the most rapidly expanding and high-yielding crops in the world (Carrasco et al., 2014). In 2013 the harvested area of oil palm plantations in Indonesia alone was 7.1 million ha, accounting for $42 \%$ of world total (17 million ha), followed by Malaysia's 4.5 million ha (FAO, 2013). Indonesia's consistently high growth rate of oil palm area (nearly 10\% annually; Gunarso et al., 2013) in the last two decades has placed it as the largest global palmoil producer, and yet it has planned to double its oil palm planted area from 9.7 million ha in 2009 to 18 million ha by 2020 (Koh and Ghazoul, 2010). Since oil palms favor a tropical-humid climate with consistently high temperatures and humidity, the plantations have converted large areas of rainforest in Indonesia including those on carbon-rich peat soils (Carlson et al., 2012).

Undisturbed forests have long-lasting capacity to store carbon (C) in comparison to disturbed or managed vegetation (Luyssaert et al., 2008). Tropical forest to oil palm conversion has significant implications on above- and belowground C stocks (Kotowska et al., 2015a). However, the exact quantification of long-term and large-scale forest-oil palm replacement effects is difficult as the greenhouse gas balance of oil palms is still uncertain due to incomplete monitoring of the dynamics of oil palm plantations (including young development stage), and lack of understanding of the $\mathrm{C}$, nitrogen $(\mathrm{N})$, water and energy exchange between oil palms, soil and the atmosphere at ecosystem scale. Besides that, the assessment of these processes in agricultural ecosystems is complicated by human activities, e.g., crop management, including planting and pruning, irrigation and fertilization, litter and residues management, and yield outputs. One of the suitable tools for evaluating the feedback of oil palm expansion is ecosystem modeling. Although a series of agricultural models exist for simulating the growth and yield of oil palm such as OPSIM (van Kraalingen et al., 1989), ECOPALM (Combres et al., 2013), APSIM-Oil Palm (Huth et al., 2014), and PALMSIM (Hoffmann et al., 2014), these models have not yet aimed at the full picture of $C$, water and energy exchanges between land and atmosphere and remain to be coupled with climate models. Given the current and potential large-scale deforestation driven by the expansion of oil palm plantations, the ecosystem services such as yield, $\mathrm{C}$ sequestration, microclimate, energy and water balance of this new managed monoculture landscape have to be evaluated in order to estimate the overall impact of land-use change on environment including regional and global climate.

Land surface modeling has been widely used to characterize the two-way interactions between climate and human activities in terrestrial ecosystems such as deforestation, agricultural expansion, and urbanization (Jin and Miller, 2011; Oleson et al., 2004). A variety of land models (or terrestrial biosphere models, see review by Fisher et al., 2014) have been adapted to simulate land-atmosphere energy and matter exchanges for major crops such as the Community Land Model (CLM, Oleson et al., 2013). CLM represents the crop and naturally vegetated land units as patches of plant functional types (PFTs) defined by their key ecological functions (Bonan et al., 2002). However, most of the crops being simulated are annual crops such as wheat, corn, soybean, etc. Their phenological cycles are usually represented as three stages of development from planting to leaf emergence, to fruit-fill and to harvest, all within a year. Attempts were also made to evaluate the climate effects of perennial deciduous crops, e.g., by extending the annual growing season to simulate earlier green-up and lagged senescence (Georgescu et al., 2011). However, the perennial evergreen crops such as oil palm, cacao, coffee, rubber, coconut, etc. and their long-term biophysical processes are not represented in the above land models yet, despite the worldwide growing demand (FAO, 2013).

Oil palm is a perennial evergreen crop which can be described by the Corner's architectural model (Hallé et al., 1978). A number of phytomers, each carrying a large leaf (frond) and axillating a fruit bunch, emerge successively (nearly two per month) from a single meristem (the bud) at the top of a solitary stem. They form a multilayer canopy with old leaves progressively being covered by new ones, until being pruned at senescence. Each phytomer has its own phenological stage and yield, according to respective position in the crown. The oil palm is productive for more than 25 years, including a juvenile stage of around 2 years. In order to capture the inter- and intra-annual dynamics of growth and yield and land-atmosphere energy, water and C fluxes in the oil palm system, a new structure and dimension detailing the phytomer-level phenology, $\mathrm{C}$ and $\mathrm{N}$ allocation and agricultural managements have to be added to the current integrated plant-level physiological parameterizations in the land models. This specific refinement needs to remain compliant with the current model structure though, and be simple to parameterize.

In this study, we develop a new CLM-Palm sub-model for simulating the growth, yield, and energy and material cycling of oil palm within the framework of CLM4.5. It introduces a sub-canopy phenological and physiological parameterization so that multiple leaf and fruit components operate in parallel but at delayed steps. A phytomer in the model is meant to represent the average condition of an age cohort of actual oil palm phytomers across the whole plantation landscape. The overall gross primary production (GPP) by leaves and C output by fruit harvests rely on the development trends of individual phytomers. The functions implemented for oil palm combine the characteristics of both trees and crops, such as the woody-like stem growth and turnover but the crop-like vegetative and reproductive allocations which enable fruit $\mathrm{C}$ and $\mathrm{N}$ output. Agricultural practices such as transplanting, fertilization and leaf pruning are also represented.

The main objectives of this paper are to (i) describe the development of CLM-Palm including its phenology, C and $\mathrm{N}$ allocation, and yield output; (ii) optimize model parameters using field-measured leaf area index (LAI) and observed 
long-term monthly yield data from a mature oil palm plantation in Sumatra, Indonesia; and (iii) validate the model against independent LAI, yield and net primary production (NPP) data from eight oil palm plantations of different age in Sumatra, Indonesia.

\section{Model development}

For adequate description of oil palm functioning, we adapted the CLM crop phenology, allocation and vegetative structure subroutines to the monopodial morphology and sequential phenology of oil palm so that each phytomer evolves independently in growth and yield (Fig. 1). Their phenology sequence is determined by the phyllochron (the period in thermal time between initiations of two subsequent phytomers) (Table A1). A maximum of 40 phytomers with expanded leaves, each growing up to $7 \mathrm{~m}$ long, are usually maintained in plantations by pruning management. There are also around 60 initiated phytomers developing slowly inside the bud. The largest ones, already emerged at the top of the crown but not yet expanded, are named "spear" leaves (Fig. 1a). Each phytomer can be considered a sub-PFT component that has its own prognostic leaf growth and fruit yield capacity but having (1) the stem and root components that are shared by all phytomers, (2) the soil water content, $\mathrm{N}$ resources, and resulting photosynthetic assimilates that are also shared and partitioned among all phytomers, and (3) a vertical structure of the foliage, with the youngest at the top and the oldest at the bottom of the canopy. Within a phytomer the fruit and leaf components do not compete for growth allocation because leaf growth usually finishes well before fruit-fill starts. However one phytomer could impact the other ones through competition for assimilates, which is controlled by the $\mathrm{C}$ - and $\mathrm{N}$-allocation subroutine according to their respective phenological stages.

Here we describe only the new phenology, allocation and agricultural management functions developed for the oil palm. Photosynthesis, respiration, water and $\mathrm{N}$ cycles, and other biophysical processes already implemented in CLM4.5 (Oleson et al., 2013) are not modified (except $\mathrm{N}$ retranslocation scheme) for the current study. The following diagram shows the new functions and their coupling with existing modules within the CLM4.5 framework (Fig. 2).

\subsection{Phenology}

Establishment of the oil palm plantation is implemented with two options: seed sowing or transplanting of seedlings. In this study, the transplanting option is used. We design seven post-planting phenological steps for the development of each phytomer: (1) leaf initiation; (2) start of leaf expansion; (3) leaf maturity; (4) start of fruit-fill; (5) fruit maturity and harvest; (6) start of leaf senescence; and (7) end of leaf senescence and pruning (Fig. 1b). The first two steps dif- (a)

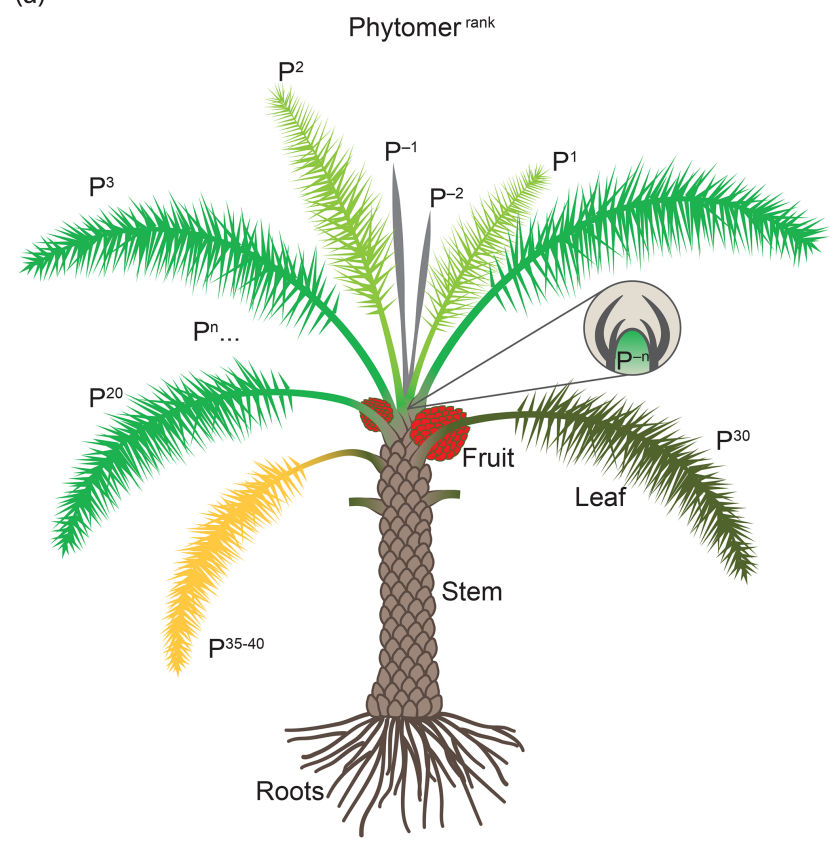

(b)

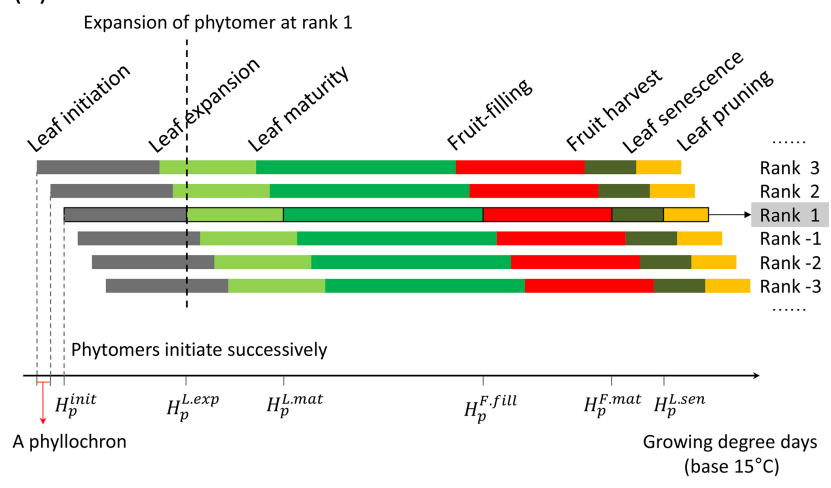

Figure 1. (a) New sub-canopy phytomer structure of CLM-Palm. $\mathrm{P}^{1}$ to $\mathrm{P}^{n}$ indicate expanded phytomers and $\mathrm{P}^{-1}$ to $\mathrm{P}^{-n}$ at the top indicate unexpanded phytomers packed in the bud. Each phytomer has its own phenology, represented by different colors corresponding to (b) the phytomer phenology: from initiation to leaf expansion, to leaf maturity, to fruit-fill, to harvest, to senescence and to pruning. Phytomers initiate successively according to the phyllochron (the period in heat unit between initiations of two subsequent phytomers). Detailed phenology description is in the Supplement.

ferentiate pre-expansion (heterotrophic) and post-expansion (autotrophic) leaf growth phases. The other steps control leaf and fruit developments independently so that leaf growth and maturity could be finished well before fruit-fill, and leaf senescence could happen after fruit harvest according to field observations. The modified phenology subroutine controls the life cycle of each phytomer (sub-PFT level) as well as the planting, stem and root turnover, vegetative maturity (start of fruiting) and final rotation (replanting) of the whole plant 


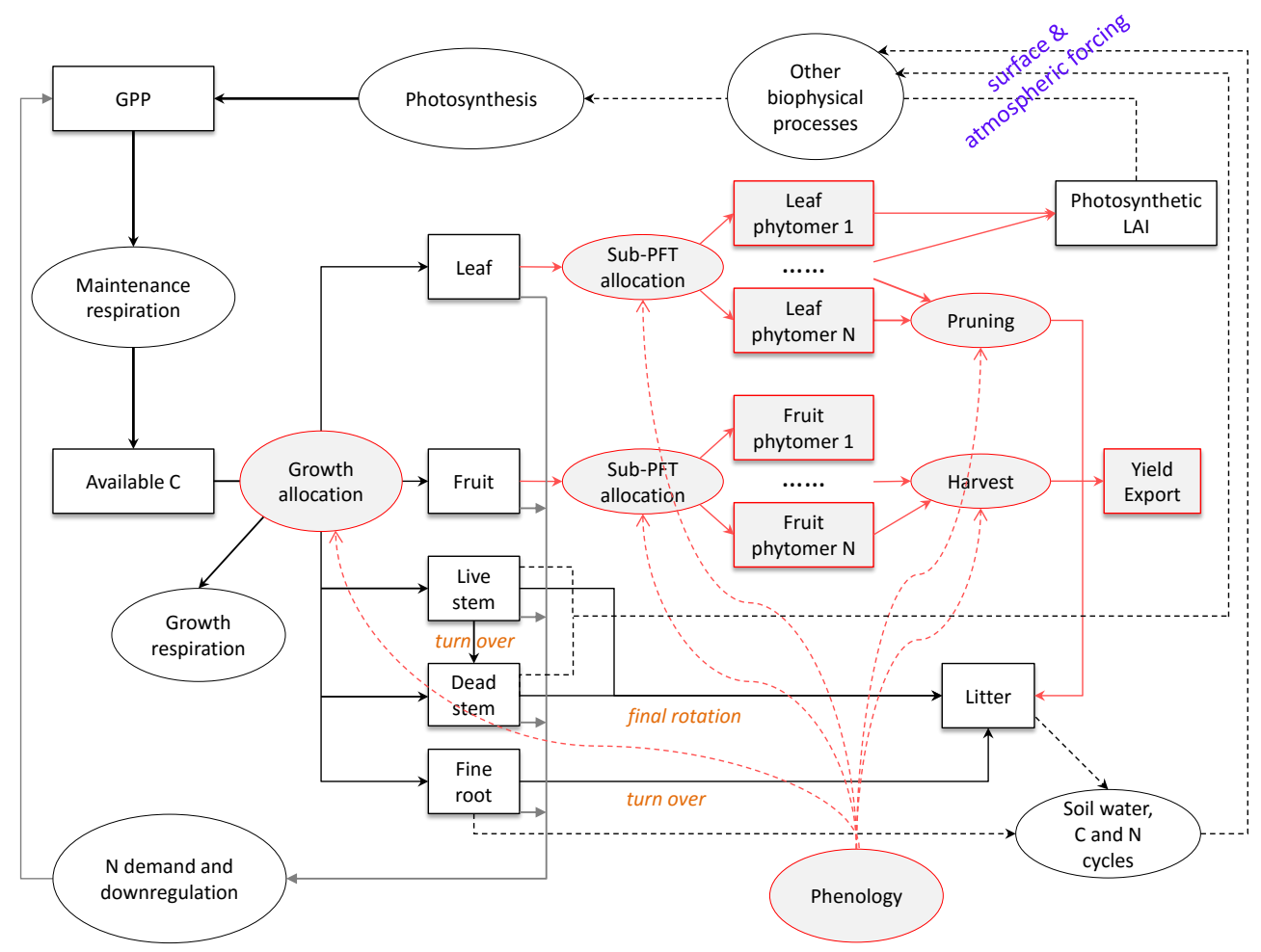

Figure 2. Original and modified structure and functions for developing CLM-Palm in the framework of CLM4.5. Original functions from CLM4.5 are represented in black or grey. New functions designed for CLM-Palm are represented in red, including phenology, allocation, pruning, fruit harvest and export, as well as the sub-canopy (sub-PFT) structure.

(PFT level). Detailed description of oil palm phenology and $\mathrm{N}$ retranslocation during senescence is in the Supplement. The main phenological parameters are in Table A1 in the Appendix.

All phytomers are assumed to follow the same phenological steps, where the thermal length for each phase is measured by growing degree days (GDDs; White et al., 1997). For oil palm, a new GDD variable with $15^{\circ} \mathrm{C}$ base temperature and 25 degree days daily maximum (Corley and Tinker, 2003; Goh, 2000; Hormaza et al., 2012) is accumulated from planting (abbr. GDD 15 ). The phenological phases are signaled by respective GDD requirements, except that pruning is controlled by the maximum number of expanded phytomers according to plantation management (Table A1). Other processes in the model such as $\mathrm{C}$ and $\mathrm{N}$ allocation for growth of new tissues respond to this phenology scheme at both PFT level and phytomer level.

\subsection{C and $\mathrm{N}$ allocation}

In CLM, the fate of newly assimilated $\mathrm{C}$ from photosynthesis is determined by a coupled $\mathrm{C}$ - and $\mathrm{N}$-allocation routine. Potential allocation for new growth of various plant tissues is calculated based on allocation coefficients and their allometric relationship (Table A2).
A two-step allocation scheme is designed for the subcanopy phytomer structure and according to the new phenology. First, available $\mathrm{C}$ (after subtracting respiration costs) is partitioned to the root, stem, overall leaf, and overall fruit pools with respect to their relative demands by dynamic allocation functions according to PFT-level phenology. The $\mathrm{C}: \mathrm{N}$ ratios for different tissues link $\mathrm{C}$ demand and $\mathrm{N}$ demand so that a $\mathrm{N}$ down-regulation mechanism is enabled to rescale GPP and $\mathrm{C}$ allocation if $\mathrm{N}$ availability from soil mineral $\mathrm{N}$ pool and retranslocated $\mathrm{N}$ pool does not meet the demand. Then, the actual $\mathrm{C}$ and $\mathrm{N}$ allocated to the overall leaf or fruit pools are partitioned between different phytomers at the subPFT level (Fig. 2). Details are described below.

\subsubsection{PFT-level allocation}

$\mathrm{C}$ and $\mathrm{N}$ allocation at the PFT level is treated distinctly before and after oil palm reaches vegetative maturity. At the juvenile stage before fruiting starts (i.e., $\mathrm{GDD}_{15}<\mathrm{GDD}_{\min }$ ) all the allocation goes to the vegetative components. The following equations are used to calculate the allometric ratios for partitioning available $\mathrm{C}$ and $\mathrm{N}$ to the leaf, stem, and root pools. 
$A_{\text {root }}=a_{\text {root }}^{\mathrm{i}}-\left(a_{\text {root }}^{\mathrm{i}}-a_{\text {root }}^{\mathrm{f}}\right) \frac{\mathrm{DPP}}{\mathrm{Age}_{\text {max }}}$,

$A_{\text {leaf }}=f_{\text {leaf }}^{\mathrm{i}} \times\left(1-A_{\text {root }}\right)$,

$A_{\text {stem }}=1-A_{\text {root }}-A_{\text {leaf }}$,

where $\frac{\mathrm{DPP}}{\mathrm{Age}_{\max }} \leq 1$, DPP is the days past planting, and $\mathrm{Age}_{\text {max }}$ is the maximum plantation age ( $\sim 25$ years). $a_{\text {root }}^{\mathrm{i}}$ and $a_{\text {root }}^{\mathrm{f}}$ are the initial and final allocation coefficients for roots and $f_{\text {leaf }}^{\mathrm{i}}$ is the initial leaf allocation coefficient before fruiting (Table A2). Root and stem allocation ratios are calculated with Eqs. (1) and (3) for all ages and phenological stages of oil palm.

After fruiting begins, the new non-linear function is used for leaf allocation:

$$
\begin{aligned}
A_{\text {leaf }} & =a_{\text {leaf }}^{2}-\left(a_{\text {leaf }}^{2}-a_{\text {leaf }}^{\mathrm{f}}\right) \times \\
& \left(\frac{\mathrm{DPP}-\mathrm{DPP}_{2}}{\mathrm{Age}_{\max } \times d_{\text {mat }}-\mathrm{DPP}_{2}}\right)^{d_{\text {alloc }}^{\text {leaf }}},
\end{aligned}
$$

where $a_{\text {leaf }}^{2}$ equals the last value of $A_{\text {leaf }}$ calculated right before fruit-fill starts and $\mathrm{DPP}_{2}$ is the days past planting right before fruit-fill starts. $d_{\text {mat }}$ controls the age when the leaf allocation ratio approaches its final value $a_{\text {leaf }}^{\mathrm{f}}$, while $d_{\text {alloc }}^{\text {leaf }}$ determines the shape of change (convex when $d_{\text {alloc }}^{\text {leaf }}<1$; concave when $\left.d_{\text {alloc }}^{\text {leaf }}>1\right) . A_{\text {leaf }}$ stabilizes at $a_{\text {leaf }}^{\mathrm{f}}$ when DPP $\geq$ $\mathrm{Age}_{\max } d_{\text {mat }}$. The equations reflect changed vegetative allocation strategy that shifts resources to leaf for maintaining LAI and increasing photosynthetic productivity when fruiting starts. The three vegetative allocation ratios $A_{\text {leaf }}, A_{\text {stem }}$ and $A_{\text {root }}$ always sum to 1 .

At the reproductive phase a fruit allocation ratio $A_{\text {fruit }}$ is introduced, which is relative to the total vegetative allocation unity. To represent the dynamics of reproductive allocation effort of oil palm, we adapt the stem allocation scheme for woody PFTs in CLM, in which increasing NPP results in increased allocation ratio for the stem wood (Oleson et al., 2013). A similar formula is used for reproductive allocation of oil palm so that it increases with increasing NPP:

$A_{\text {fruit }}=\frac{2}{1+e^{-b\left(\mathrm{NPP}_{\text {month }}-100\right)}}-a$,

where NPP month is the monthly sum of NPP from the previous month calculated with a run-time accumulator in the model. The number $100\left(\mathrm{~g} \mathrm{C} \mathrm{m}^{-2}\right.$ month $\left.^{-1}\right)$ is the base monthly NPP when the palm starts to yield (Kotowska et al., 2015a). Parameters $a$ and $b$ adjust the base allocation rate and the slope of change, respectively (Table A2). This function generates a dynamic curve of $A_{\text {fruit }}$ increasing from the beginning of fruiting to full vegetative maturity, which is used in the allocation allometry to partition assimilates between vegetative and reproductive pools (Fig. 3).

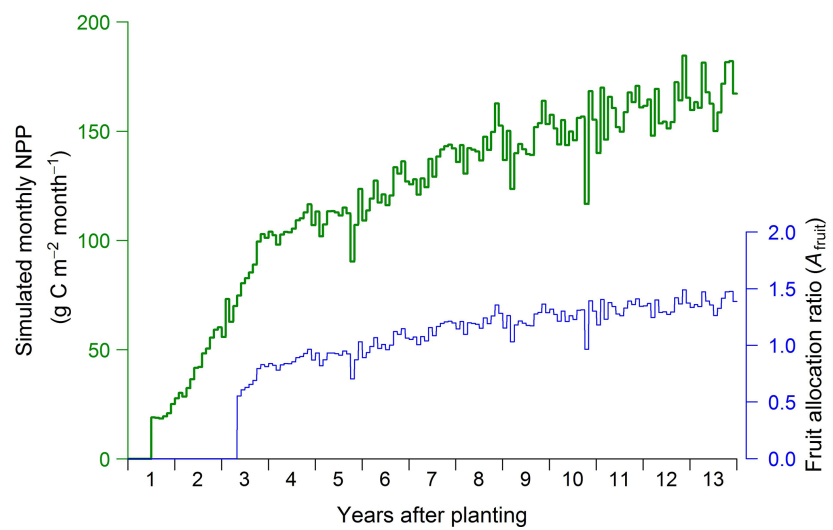

Figure 3. Time course of reproductive allocation rate (blue line) in relation to monthly NPP from the previous month NPP $_{\text {month }}$, green line) according to Eq. (5). $A_{\text {fruit }}$ is relative to the vegetative unity $\left(A_{\text {leaf }}+A_{\text {stem }}+A_{\text {root }}=1\right.$ and $\left.0 \leq A_{\text {fruit }} \leq 2\right)$. The data shown here were simulated with calibrated parameters for the PTPN-VI site.

\subsubsection{Sub-PFT (phytomer)-level allocation}

Total leaf and fruit allocations are partitioned to the different phytomers according to their phenological stages. Fruit allocation per phytomer is calculated with a sink size index:

$S_{p}^{\text {fruit }}=\frac{\mathrm{GDD}_{15}-H_{p}^{\mathrm{F} . \text { fill }}}{H_{p}^{\text {F.mat }}-H_{p}^{\text {F.fill }}}$,

where $p$ stands for the phytomer number, $H_{p}^{\text {F.fill }}$ and $H_{p}^{\text {F.mat }}$ are the phenological indices for the start of fruit-fill and fruit maturity (when $H_{p}^{\text {Ffill }} \leq \mathrm{GDD}_{15} \leq H_{p}^{\text {F.mat }}$ ). $S_{p}^{\text {fruit }}$ increases from zero at the beginning of fruit-fill to the maximum of 1 right before harvest for each phytomer. This is because the oil palm fruit accumulates assimilates at increasing rate during development until the peak when it becomes ripe and oil synthesis dominates the demand (Corley and Tinker, 2003). The sum of $S_{p}^{\text {fruit }}$ for all phytomers gives the total reproductive sink size index. Each phytomer receives a portion of fruit allocation by $\frac{S_{p}^{\text {fruit }}}{\sum_{p=1}^{n} S_{p}^{\text {fruit }}} \times A_{\text {fruit }}$, where $A_{\text {fruit }}$ is the overall fruit allocation by Eq. (5).

An important allocation strategy for leaf is the division of displayed versus storage pools for the pre-expansion and post-expansion leaf growth phases. These two types of leaf C and $\mathrm{N}$ pools are distinct in that only the displayed pools contribute to LAI growth, whereas the storage pools support the growth of unexpanded phytomers, i.e., bud and spear leaves, which remain photosynthetically inactive. Total $\mathrm{C}$ and $\mathrm{N}$ allocation to the overall leaf pool is divided to the displayed and storage pools by a fraction $\mathrm{lf}_{\mathrm{disp}}$ (Table A2) according to the following equation:

$A_{\text {leaf }}^{\text {display }}=\operatorname{lf}_{\text {disp }} \times A_{\text {leaf }}$,
$A_{\text {leaf }}^{\text {storage }}=\left(1-\mathrm{lf}_{\text {disp }}\right) \times A_{\text {leaf }}$. 
The plant level $A_{\text {leaf }}^{\text {display }}$ and $A_{\text {leaf }}^{\text {storage }}$ are then distributed evenly to expanded and unexpanded phytomers, respectively, at each time step. When a phytomer enters the leaf expansion phase, $\mathrm{C}$ and $\mathrm{N}$ from its leaf storage pools transfer gradually to the displayed pools during the expansion period. Therefore, a transfer flux is added to the real-time allocation flux and they together contribute to the post-expansion leaf growth.

LAI is calculated only for each expanded phytomer according to a constant specific leaf area (SLA) and prognostic amount of leaf $\mathrm{C}$ accumulated by phytomer $n$. In case it reaches the prescribed maximum (PLAI $\left.\mathrm{I}_{\max }\right)$, partitioning of leaf $\mathrm{C}$ and $\mathrm{N}$ allocation to this phytomer becomes zero.

\subsection{Other parameterizations}

$\mathrm{N}$ retranslocation is performed exclusively during leaf senescence and stem turnover. A part of $\mathrm{N}$ from senescent leaves and from the portion of live stem that turns dead is remobilized to a separate $\mathrm{N}$ pool that feeds plant growth or reproductive demand. $\mathrm{N}$ of fine roots is all moved to the litter pool during root turnover. We do not consider $\mathrm{N}$ retranslocation from live leaves, stem and roots specifically during grain-fill that is designed for annual crops (Drewniak et al., 2013) because oil palm has continuous fruit-fill year around at different phytomers.

The fertilization scheme for oil palm is adapted to the plantation management generally carried out in our study area, which applies fertilizer biannually, starting only 6 years after planting, assuming each fertilization event lasts 1 day. Currently the CLM-CN belowground routine uses an unrealistically high denitrification rate under conditions of $\mathrm{N}$ saturation, e.g., after fertilization, which results in a $50 \%$ loss of any excess soil mineral $\mathrm{N}$ per day (Oleson et al., 2013). This rendered the simple biannual regular fertilization nearly useless because peak $\mathrm{N}$ demand by oil palm is hard to predict given its continuous fruiting and vegetative growth, and most fertilized $\mathrm{N}$ is thus lost in several days. The high denitrification factor has been recognized as an artifact (Drewniak et al., 2013; Tang et al., 2013). According to a study on a banana plantation in the tropics (Veldkamp and Keller, 1997), around $8.5 \%$ of fertilized $\mathrm{N}$ is lost as nitrogen oxide $\left(\mathrm{N}_{2} \mathrm{O}\right.$ and $\left.\mathrm{NO}\right)$. Accounting additionally for a larger amount of denitrification loss to gaseous $\mathrm{N}_{2}$, we modified the daily denitrification rate from 0.5 to 0.001 , which gives a $30 \%$ annual loss of $\mathrm{N}$ due to denitrification that matches global observations (Galloway et al., 2004).

The irrigation option is turned off because oil palm plantations in the study area are usually not irrigated. Other input parameters for oil palm such as its optical, morphological, and physiological characteristics are summarized in Table A3. Most of them are generalized over the life of oil palm.

\section{Model evaluation}

\subsection{Site data}

Two oil palm plantations in the Jambi province of Sumatra, Indonesia, provide data for calibration. One is a mature industrial plantation at PTPN-VI $\left(01^{\circ} 41.6^{\prime} \mathrm{S}, 103^{\circ} 23.5^{\prime} \mathrm{E}\right.$; $2186 \mathrm{ha}$ ) planted in 2002, which provides long-term monthly harvest data (2005 to 2014). Another is a 2-year-old plantation at a nearby smallholder site Pompa Air $\left(01^{\circ} 50.1^{\prime} \mathrm{S}\right.$, $\left.103^{\circ} 17.7^{\prime} \mathrm{E} ; 5.7 \mathrm{ha}\right)$. The leaf area and dry weight at multiple growth stages were measured by sampling leaflets of phytomers at different ranks $(+1$ to +20$)$ on a palm and repeating for three different ages within the two plantations. The input parameter SLA (Table A2) was derived from leaf area and dry weight (excluding the heavy rachis). The phytomerlevel LAI was estimated based on the number of leaflets (90300) per leaf of a certain rank, and the PFT-level LAI was estimated by the number of expanded leaves (35-45) per palm of a certain age. In both cases, a planting density of 156 palms per hectare $(8 \mathrm{~m} \times 8 \mathrm{~m}$ per palm) was used according to observation.

Additionally, LAI, yield and NPP measurements from eight independent smallholder oil palm plantations $(50 \mathrm{~m} \times 50 \mathrm{~m}$ each) were used for model validation (Table 1). Four of these sites (HO1, HO2, HO3, HO4) are located in the Harapan region nearby PTPN-VI, and another four (BO2, BO3, BO4, BO5) are in Bukit Duabelas region $\left(02^{\circ} 04^{\prime} \mathrm{S}, 102^{\circ} 47^{\prime} \mathrm{E}\right)$, both in Jambi, Sumatra. Fresh bunch harvest data were collected at these sites for a whole year in 2014. Harvest records from both PTPN-VI and the eight validation sites were converted to harvested $\mathrm{C}$ $\left(\mathrm{g} \mathrm{C} \mathrm{m}^{-2}\right)$ with mean wet / dry weight ratio of $58.65 \%$ and $\mathrm{C}$ content $60.13 \%$ per dry weight according to $\mathrm{C}: \mathrm{N}$ analysis (Kotowska et al., 2015a). The oil palm monthly NPP and its partitioning between fruit, leaf, stem and root were estimated based on measurements of fruit yield (monthly), pruned leaves (monthly), stem increment (every 6 months) and fine root samples (once in a interval of 6-8 months) at the eight validation sites (Kotowska et al., 2015b).

The amount of fertilization at the industrial plantation PTPN-VI was $456 \mathrm{~kg} \mathrm{Nha}^{-1}$ year $^{-1}$, applied regularly twice per year starting 6 years after planting. The smallholder plantations in Harapan (H plots) and Bukit Duabelas (B plots) used much less fertilizer. From interview data, the $\mathrm{H}$ plots had roughly regular $\mathrm{N}$ fertilization (twice per year), whereas among the B plots only BO3 indicated one fertilization event per year, but the amount was unclear (applied chicken manure in 2013) and the other plots had no $\mathrm{N}$ fertilization in 2013 and 2014 due to financial difficulty. Fertilization history prior to 2013 is unavailable for all the smallholder plantations. Given the limited information, we consider two levels of fertilization for $\mathrm{H}$ plots (regular: $96 \mathrm{~kg} \mathrm{Nha}^{-1}$ year $^{-1}$, from 6 years until 2014) and B plots 
Table 1. Site conditions and N-fertilization records at the calibration and validation plots.

\begin{tabular}{lcclcll}
\hline Site & $\begin{array}{c}\text { Year of } \\
\text { planting }\end{array}$ & $\begin{array}{c}\text { Precipitation } \\
\left(\mathrm{mm} \mathrm{year}^{-1}\right)\end{array}$ & Soil type & $\begin{array}{c}\text { Fertilization } \\
\left(\mathrm{kg} \mathrm{Nh}^{-1} \text { year }^{-1}\right) \\
\text { period }\end{array}$ & \\
\hline PTPN-VI & 2002 & 2567 & loam Acrisol & 456 & $2008-2014$ & industrial plantation; others are smallholders \\
Pompa Air & 2012 & 2567 & loam Acrisol & - & - & N fertilization from 6 years onward \\
HO1 & 1997 & 2567 & loam Acrisol & 96 & $2003-2014$ & regular fertilization \\
HO2 & 1999 & 2567 & loam Acrisol & 96 & $2005-2014$ & regular fertilization \\
HO3 & 1996 & 2567 & loam Acrisol & 96 & $2002-2014$ & regular fertilization \\
HO4 & 2003 & 2567 & loam Acrisol & 96 & $2009-2014$ & regular fertilization \\
BO2 & 2000 & 2902 & clay Acrisol & 24 & $2006-2012$ & reduced fertilization \\
BO3 & 2001 & 2902 & clay Acrisol & 24 & $2007-2012$ & reduced fertilization \\
BO4 & 2002 & 2902 & clay Acrisol & 24 & $2008-2012$ & reduced fertilization \\
BO5 & 2004 & 2902 & clay Acrisol & 24 & $2010-2012$ & reduced fertilization \\
\hline
\end{tabular}

(reduced: $24 \mathrm{~kg} \mathrm{~N} \mathrm{ha}^{-1}$ year $^{-1}$, from 6 years until 2012), respectively (Table 1).

The mean annual rainfall (the WorldClim database: http: //www.worldclim.org (Hijmans et al., 2005); average of 50 years) of the two investigated landscapes in Jambi province was $\sim 2567 \mathrm{~mm}$ year $^{-1}$ in the Harapan region (including PTPN-VI) and $\sim 2902 \mathrm{~mm}$ year $^{-1}$ in the Bukit Duabelas region. In both areas, May to September represented a markedly drier season (30\% less precipitation) in comparison to the rainy season between October and April. Air temperature is relatively constant throughout the year with an annual average of $26.7^{\circ} \mathrm{C}$. In both landscapes, the principal soil types are Acrisols: in the Harapan landscape loam Acrisols dominate, whereas in Bukit Duabelas the majority is clay Acrisol. Soil texture such as sand / silt/ clay ratios and soil organic matter $\mathrm{C}$ content were measured at multiply soil layers (down to $2.5 \mathrm{~m}$ ) (Allen et al., 2015). They were used to create two sets of surface input data for the two regions separately.

\subsection{Model setup}

The model modifications and parameterizations were implemented according to CLM4.5 standards. A new sub-PFT dimension called phytomer was added to all the new variables so that the model can output history tapes of their values for each phytomer and prepare restart files for model stop and restart with bit-for-bit continuity. Simulations were set up in point mode (a single $0.5 \times 0.5^{\circ}$ grid) at every $30 \mathrm{~min}$ time step. A spin-up procedure (Koven et al., 2013) was followed to get a steady-state estimate of soil $\mathrm{C}$ and $\mathrm{N}$ pools, with the CLM-CN decomposition cascade and broadleaf evergreen tropical forest PFT. The soil $\mathrm{C}$ and $\mathrm{N}$ pools were rescaled to match the average field observation at two reference lowland rainforest sites in Harapan and Bukit Duabelas regions (Allen et al., 2015; Guillaume et al., 2015), which serve as the initial conditions. The forest was replaced with the oil palm at a specific year of plantation establishment (2002 for
PTPN-VI and 1996, 1997, 1999, 2000, 2001, 2002, 2003, and 2004 for $\mathrm{HO} 3, \mathrm{HO} 1, \mathrm{HO} 2, \mathrm{BO} 2, \mathrm{BO} 3, \mathrm{BO} 4, \mathrm{HO} 4$, and $\mathrm{BO} 5$, respectively). The oil palm functions were then turned on and simulations continued until 2014. The 3-hourly ERAInterim climate data (Dee et al., 2011) were used as atmospheric forcing.

\subsection{Calibration of key parameters}

A simulation from 2002 to 2014 at the PTPN-VI site was used for model calibration. Both the PFT-level and phytomerlevel LAI development were calibrated with field observations in 2014 from a chronosequence approach (space for time substitution) using oil palm samples of three different ages and multiple phytomers of different rank (Sect. 3.1). Simulated yield outputs (around twice per month) were calibrated with monthly harvest records of PTPN-VI plantation from 2005 to 2014. Cumulative yields were compared because the timing of harvest in the plantations was largely uncertain and varied depending on weather and other conditions.

To simplify model calibration, we focused on parameters related to the new phenology and allocation processes. Phenological parameters listed in Table A1 were determined according to field observations and existing knowledge about oil palm growth phenology (Combres et al., 2013; Corley and Tinker, 2003) as well as plantation management in Sumatra, Indonesia. Allocation coefficients in Table A2 were more uncertain, and they were the key parameters to optimize in order to match observed LAI and yield dynamics according to the following sensitivity analysis. Measurements of oil palm NPP and its partitioning between fruit, canopy, stem, and root from the eight sites (Sect. 3.1) were used as a general reference when calibrating the allocation coefficients.

Leaf $\mathrm{C}: \mathrm{N}$ ratio and SLA were determined by field measurements. Other $\mathrm{C}: \mathrm{N}$ ratios and optical and morphological parameters in Table A3 were either fixed by field observations or adjusted in between trees and crops. 


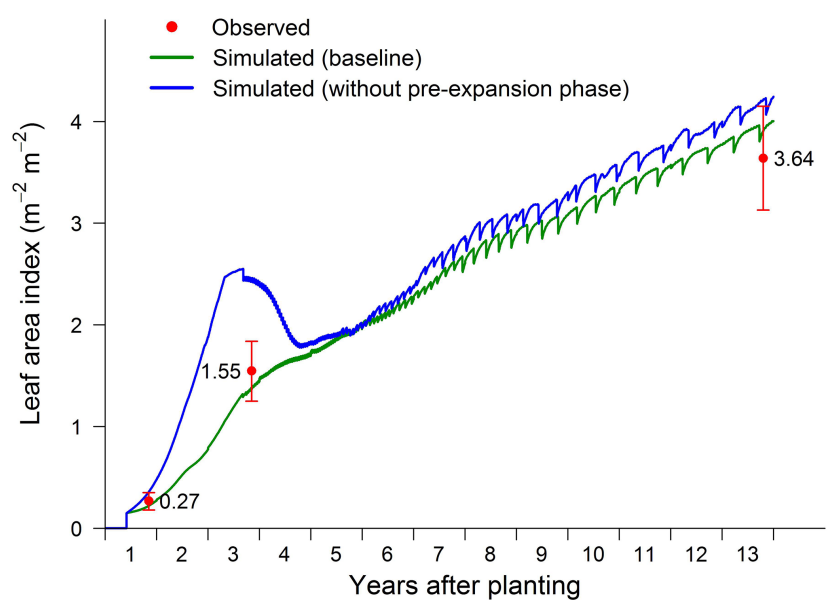

Figure 4. PFT-level LAI simulated by CLM-Palm, with and without the pre-expansion growth phase in the phytomer phenology and compared to field measurements used for calibration. The initial sudden increase at year 1 represents transplanting from nursery. The sharp drops mark pruning events.

\subsection{Sensitivity analysis}

Performing a full sensitivity analysis of all parameters used in simulating oil palm (more than 100 parameters, though a majority are shared with natural vegetation and other crops) would be a challenging work. As with calibration, we limited the sensitivity analysis to a set of parameters introduced for the specific PFT and model structure designed for oil palm (Tables A1 and A2). Among the phenological parameters, mxlivenp (maximum number of expanded phytomers) and phyllochron (Table A1) are closely related to pruning frequency, but they should not vary widely for a given oil palm breed and plantation condition. Therefore, they were fixed at the average level for the study sites in Jambi, Sumatra. Parameter PLAI $\mathrm{max}_{\max }$ is only meant for error controlling, although in our simulations phytomer-level LAI never reached PLAI $_{\max }$ (see Fig. 5 in results) because environmental constraints and $\mathrm{N}$ down-regulation already limited phytomer leaf growth well within the range. $\mathrm{GDD}_{\text {init }}$ was kept to zero because only the transplanting scenario was considered for seedling establishment.

We tested two hypotheses of phytomer-level leaf development based on the other phenological parameters: (1) considering the leaf storage growth period - that is, the bud and spear leaf phase is explicitly simulated with the GDD parameters in Table A1 and $\mathrm{lf}_{\mathrm{disp}}=0.3$ in Table A2; (2) excluding the storage growth period by setting $\mathrm{GDD}_{\mathrm{exp}}=0$ and $\mathrm{If}_{\text {disp }}=1$ so that leaf expands immediately after initiation and leaf $\mathrm{C}$ and $\mathrm{N}$ allocation all goes to the photosynthetic active pools.

The sensitivity of allocation and photosynthesis parameters in Table A2 were tested by adding or subtracting 10 or $30 \%$ to the baseline values (calibrated) one by one and calcu-

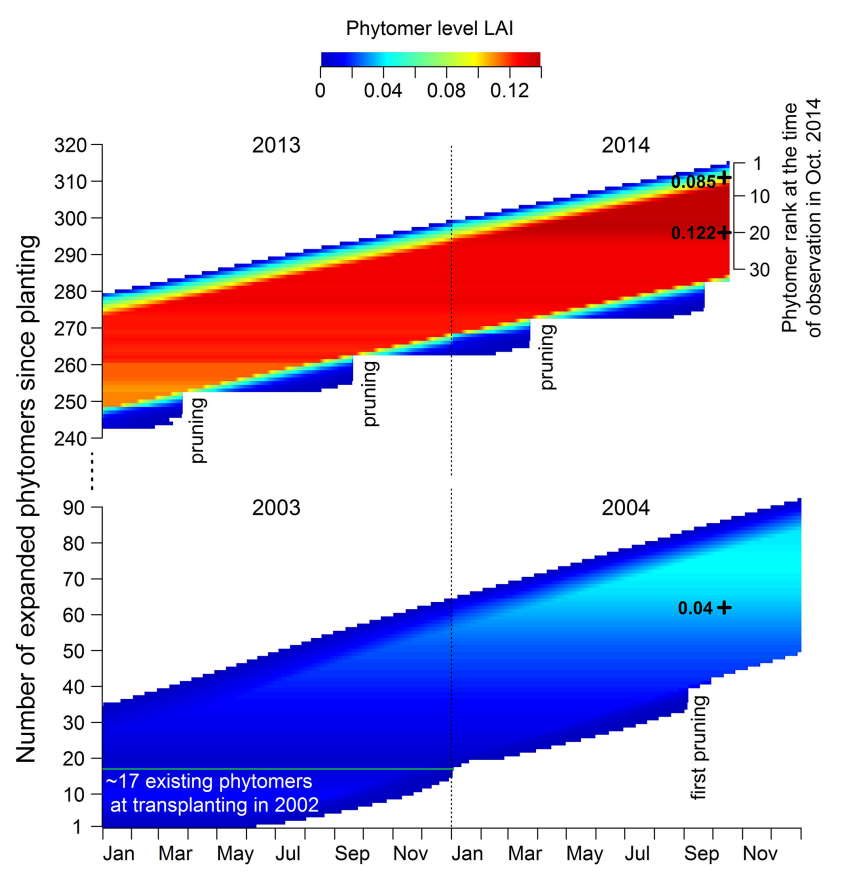

Figure 5. Simulated phytomer-level LAI dynamics (horizontal color bar) compared with field observations (black crosses with measured LAI values). A phytomer in the model is only meant to represent the average condition of an age cohort of actual oil palm phytomers across the whole plantation landscape. The newly expanded phytomer at a given point of time has a rank of 1. Each horizontal bar represents the life cycle of a phytomer after leaf expansion. Phytomers emerge in sequence, and the $y$ axis gives the total number of phytomers that have expanded since transplanting in the field. Senescent phytomers are pruned.

lating their effect on final cumulative yield at the end of simulation (December 2014). In fact, all the allocation parameters are interconnected because they co-determine photosynthesis capacity and respiration costs as partitioning to the different vegetative and reproductive components varies. This simple approach provides a starting point to identify sensitive parameters, although a more sophisticated sensitivity analysis is needed in the future.

\subsection{Validation}

In this study, we only validated the model structure and model behavior on simulating aboveground $\mathrm{C}$ dynamics and partitioning as represented by LAI, fruit yield and NPP. Independent leaf measurement, yield and monthly NPP data collected in 2014 from the eight mature oil palm sites $(H$ and B plots) were compared with the eight simulations using the same model settings and calibrated parameters, except that two categories of climate forcing, surface input data (for soil texture) and fertilization (regular vs. reduced) were prescribed for the $\mathrm{H}$ plots and $\mathrm{B}$ plots, respectively. 


\section{Results}

\subsection{Calibration with LAI and yield}

In calibration with the industrial PTPN-VI plantation, the PFT-level LAI dynamics simulated by the model incorporating the pre-expansion phase matches well with the LAI measurements for three different ages (Fig. 4). Simulated LAI for the PFT increases with age in a sigmoid relationship. The dynamics of LAI is also impacted by pruning and harvest events because oil palms invest around half of their assimilates into fruit yield. Oil palms are routinely pruned by farmers to maintain the maximum number of expanded leaves around 40 . Hence, when yield begins $2-3$ years after planting, LAI recurrently shows an immediate drop after pruning and then quickly recovers. The pruning frequency decreases with age because the phyllochron increases to 1.5 times at 10 years old (Supplement). Simulations without the pre-expansion storage growth phase show an unrealistic fast increase of LAI before 3 years old, much higher than observed in the field. At older age after yield begins, LAI drops drastically and recovers afterwards. Although the final LAI could stabilize at a similar level, the initial jump and drop of LAI at young stage do not match field observations and cannot be solved by adjusting parameters other than GDD $\mathrm{Dxp}_{\text {exp }}$. Hereafter, all simulations were run using the pre-expansion phase.

The phytomer-level LAI development is comparable with leaf samples from the field (Fig. 5). The two leaf samples at rank $5(\mathrm{LAI}=0.085)$ and rank $20(\mathrm{LAI}=0.122)$ of a mature oil palm in PTPN-VI (the two black crosses for 2014) are slightly lower than simulated values $(0.089$ and 0.138 , respectively). The other sample at rank 25 ( $\mathrm{LAI}=0.04$, for 2004) of a young oil palm in Pompa Air is slightly higher than the simulated value (0.036). Each horizontal color bar clearly marks the post-expansion leaf phenology cycle, including gradual increment of photosynthetic LAI during phytomer development and gradual declining during senescence. The pre-expansion phase is not included in the figure, but model outputs show that roughly $60-70 \%$ of leaf $\mathrm{C}$ in a phytomer is accumulated before leaf expansion, which is codetermined by the allocation ratio $\mathrm{lf}_{\text {disp }}$ and the lengths of two growth phases set by $\mathrm{GDD}_{\exp }$ and $\mathrm{GDD}_{\mathrm{L} \text {.mat }}$. This is comparable to observations on coconut palm that dry mass of the oldest unexpanded leaf accounts for $60 \%$ of that of a mature leaf (Navarro et al., 2008). Only when the palm becomes mature, phytomer LAI could come closer to the prescribed PLAI $_{\max }(0.165)$. However, during the whole growth period from 2002 to 2014 none of the phytomers have reached PLAI $_{\max }$, which is the prognostic result of the $\mathrm{C}$ balance simulated by the model.

The cumulative yield of baseline simulation has overall high consistency with harvest records (Fig. 6). The mean percentage error (MPE) is only $3 \%$. The slope of simulated curve increases slightly after 2008 when the LAI continues to increase and NPP reaches a high level (Fig. 3). The harvest

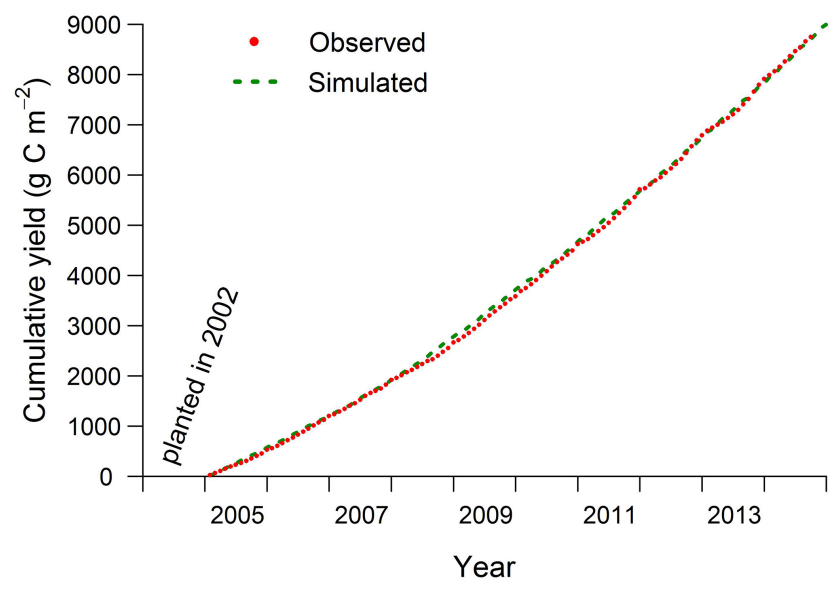

Figure 6. Simulated PFT-level yield compared with monthly harvest data (2005-2014) from the calibration site PTPN-VI in Jambi, Sumatra. CLM-Palm represents multiple harvests from different phytomers (about twice per month). The cumulative harvest amounts throughout time are compared.

records also show the same pattern after 2008 when heavy fertilization began $\left(456 \mathrm{~kg} \mathrm{~N} \mathrm{ha}^{-1}\right.$ year $\left.^{-1}\right)$.

The per-month harvest records exhibit strong zigzag pattern (Fig. 7). One reason is that oil palms are harvested every 15-20 days, and summarizing harvest events by calendar month would result in uneven harvest times per month (e.g., two harvests fall in a previous month and only one in the next month). Yet it still shows that harvests at PTPN-VI plantation dominated from October to December whereas in the earlier months of each year harvest amounts were significantly lower. The simulated monthly yield has less seasonal fluctuation, but it corresponds to the general pattern of precipitation (Fig. 7). A significant positive linear correlation exists between simulated yield (detrended to minimize phenological effects) and the accumulative precipitation of a 120-day period (the main fruit-filling and oil synthesis period) before each harvest event (Pearson's $r=0.32, p$ value $<1 \times 10^{-6}$ ). Examining the longer term year-to-year variability, a clear increasing trend of yield with increasing plantation age is captured by the model, largely matching field records since the plantation began to yield in 2005 .

\subsection{Sensitivity analysis}

The leaf $\mathrm{N}$ fraction in Rubisco $\left(F_{\mathrm{LNR}}\right)$ is shown to be the most sensitive parameter (Fig. 8), because it determines the maximum rate of carboxylation at $25^{\circ} \mathrm{C}\left(V_{\mathrm{cmax} 25}\right)$ together with SLA (also sensitive), foliage $\mathrm{N}$ concentration $\left(\mathrm{CN}_{\text {leaf }}\right.$, Table A3) and other constants. Given the fact that $F_{\mathrm{LNR}}$ should not vary widely in nature for a specific plant, we constrained this parameter within narrow boundaries to get a $V_{\mathrm{cmax} 25}$ around 100.7 , the same as that shared by all other crop PFTs in CLM. We fixed SLA to 0.013 by field measurements. The value is only representative of the photosynthetic 


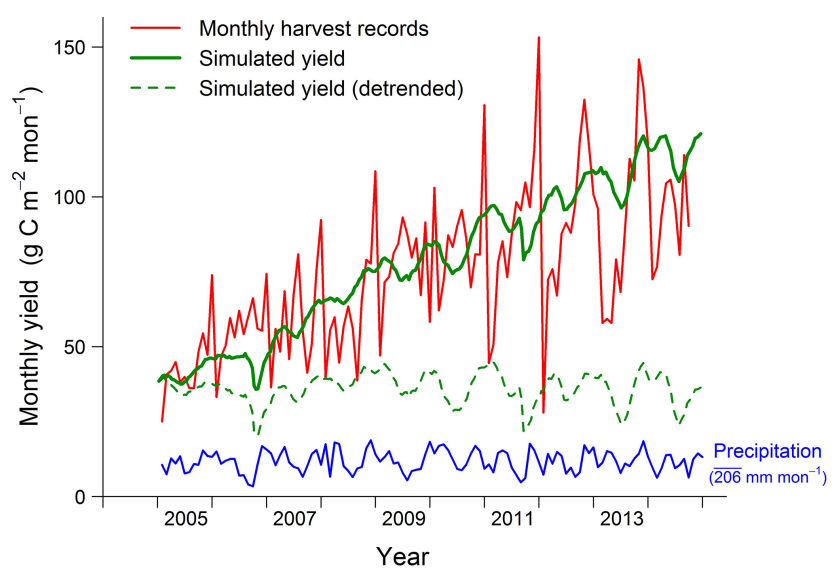

Figure 7. Comparison of simulated and observed monthly yield at PTPN-VI. The modeled yield outputs are per harvest event (every 15-20 days depending on the phyllochron), while harvest records are the summary of harvest events per month. The model output is thus rescaled to show the monthly trend of yield that matches the mean of harvest records, given that the cumulative yields are almost the same between simulation and observation as shown in Fig. 6 . The detrended curve is to facilitate comparison with the dynamics of monthly mean precipitation.

leaflets. The initial root allocation ratio $\left(a_{\text {root }}^{\mathrm{i}}\right)$ has considerable influence on yield because it modifies the overall respiration cost along the gradual declining trend of fine root growth across 25 years (Eq. 1). The final ratio $\left(a_{\text {root }}^{\mathrm{f}}\right)$ has limited effects because its baseline value (0.1) is set very low and thus the percentage changes are insignificant. The leaf allocation coefficients $\left(f_{\text {leaf }}^{\mathrm{i}}, a_{\text {leaf }}^{\mathrm{f}}\right)$ are very sensitive parameters because they determine the magnitudes of LAI and GPP and consequently yield. The coefficients $d_{\text {mat }}$ and $d_{\text {alloc }}^{\text {leaf }}$ control the nonlinear curve of leaf development (Eq. 4) and hence the dynamics of NPP and that partitioned to fruits. Increased $F_{\text {stem }}^{\text {live }}$ results in higher proportion of live stem throughout life, given the fixed stem turnover rate (Supplement), and therefore it brings higher respiration cost and lower yield. The relative influence of fruit allocation coefficients $a$ and $b$ on yield is much lower than the leaf allocation coefficients because of the restriction of $A_{\text {fruit }}$ by NPP dynamics (Eq. 5). Parameters $1 f_{\text {disp }}$ and transplant have negligible effects. $1 f_{\text {disp }}$ has to work together with the phenological parameter GDD $\mathrm{exp}_{\text {to give a }}$ reasonable size of spear leaves before expansion according to field observation. The sensitivity of $\mathrm{GDD}_{\exp }$ is shown in Fig. 4. Varying the size of seedlings at transplanting by 10 or $30 \%$ does not alter the final yield, likely because the initial LAI is still within a limited range $(0.1-0.2)$ given the baseline value 0.15 .

\subsection{Model validation with independent data set}

The LAI development curves for the eight oil palm sites follow similar patterns since field transplanting in different years, except that the $\mathrm{B}$ plots $(\mathrm{BO} 2, \mathrm{BO} 3, \mathrm{BO} 4)$ are re-

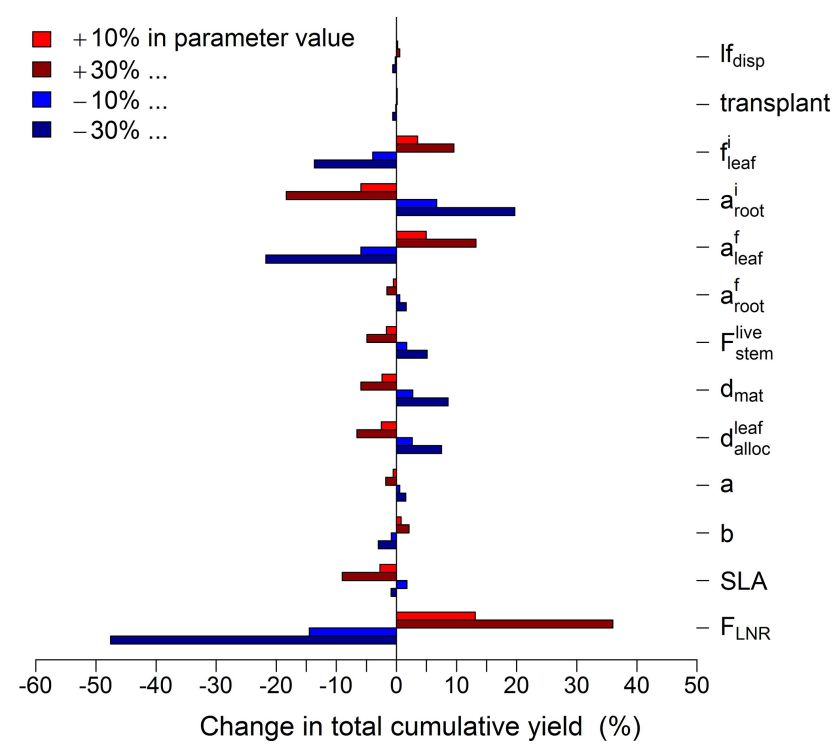

Figure 8. Sensitivity analysis of key allocation parameters in regard of the cumulative yield at the end of simulation, with two magnitudes of change in the value of a parameter one by one while others are held at the baseline values in Table A2.

strained in LAI growth after 11 years because of reduced fertilization (Fig. 9a). The field data in 2014 also show the check by $\mathrm{N}$ limitation and even exhibit a decreasing trend of LAI with increasing plantation age at B plots except BO5, which is under 10 years old (Fig. 9b). In general, the modeled LAI has a positive relationship with plantation age under regularly fertilized condition and it stabilizes after 15 years (site HO3) as controlled by $d_{\text {mat }}$ (Eq. 4). This age-dependent trend is observed in the field with a notable deviation by site HO1. The average LAI of the eight sites from the model is comparable with field measurements in 2014 (MPE $=13 \%$ ). There are large uncertainties in field LAI estimates because we did not measure LAI at the plot level directly but only sampled leaf area and dry weight of individual phytomers and scaled the values up.

The simulated annual yields match closely field observations in 2014 at both the $\mathrm{H}$ plots $(\mathrm{MPE}=2 \%$ ) and $\mathrm{B}$ plots $(\mathrm{MPE}=2 \%$; Fig. 10). With regular fertilization in the $\mathrm{H}$ plots, both the modeled and observed yield are slightly higher in the older plantations $(\mathrm{HO} 2, \mathrm{HO} 1$, and $\mathrm{HO} 3$ ) than the younger one (HO4) but stabilize around $1280 \mathrm{~g} \mathrm{C} \mathrm{m}^{-2}$ year $^{-1}$ past the age of 15 years. In contrast, the B plots have significantly lower yield because of reduced $\mathrm{N}$ input and the model is able to capture the $\mathrm{N}$ limitation effect on both NPP and yield (i.e., the declining trend with increasing age), which is consistent with field observations. The model simulates slightly higher NPP than field estimates at seven smallholder sites (MPE $=10 \%$ ) using the input parameters calibrated and optimized only for LAI and yield at the industrial PTPN-VI plantation. It needs to be noted that field measured NPP at the validation sites (Sect. 3.1) does not 


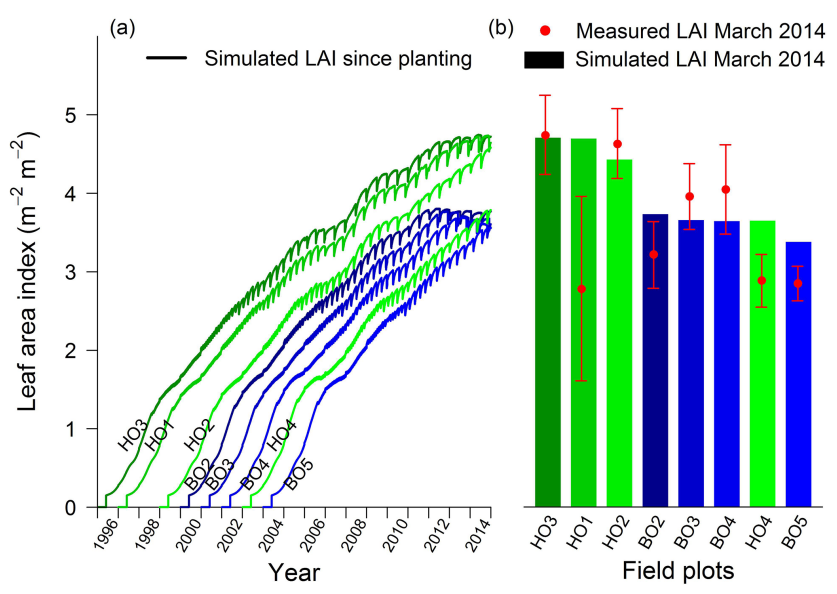

Figure 9. Validation of LAI with eight independent oil palm sites (sequence in plantation age) from the Harapan (regular fertilization) and Bukit Duabelas (reduced fertilization) regions: (a) shows the LAI development of each site simulated by the model since planting; (b) shows the comparison of field measured LAI in 2014 with model.

consider the growing size of canopy (i.e., increasing LAI), which could partly explain the lower observed than simulated NPP at most sites.

\section{Discussion}

Calibration and validation with multiple site data demonstrate the utility of CLM-Palm and its sub-canopy structure for simulating the growth and yield of the unique oil palm plantation system within a land surface modeling context.

The pre-expansion phenological phase is proved necessary for simulating both phytomer-level and PFT-level LAI development in a prognostic manner. The leaf C-storage pool provides an efficient buffer to support phytomer development and maintain overall LAI during fruiting. It also avoids an abnormally fast increase of LAI in the juvenile stage when $\mathrm{C}$ and $\mathrm{N}$ allocation is dedicated to the vegetative components. Without the leaf storage pool, the plant's canopy develops unrealistically fast at young age and then enters an emergent drop once fruit-fill begins (Fig. 4). This is because the plant becomes unable to sustain leaf growth just from its current photosynthetic assimilates when a large portion is allocated to fruits.

The model well simulates year-to-year variability in yield (Fig. 7), in which the increasing trend is closely related to the fruit allocation function (Fig. 3) and LAI development (Fig. 4). The seasonal variability in simulated yield corresponds to the precipitation data which is involved in the coupled stomatal conductance and photosynthesis and other hydrological processes in the model. But it is difficult to interpret the difference from monthly harvest records due to the artificial zigzag pattern. The harvest records from planta-

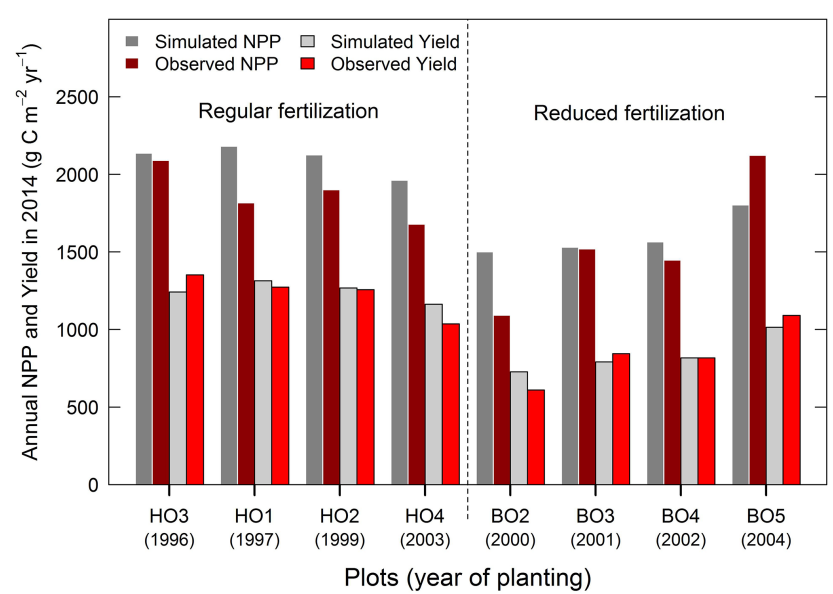

Figure 10. Validation of yield and NPP with eight independent oil palm sites from the Harapan $(\mathrm{H})$ and Bukit Duabelas (B) regions with different fertilization treatments. Field data were collected in 2014.

tions do not necessarily correspond to the amount of mature fruits along a phenological timescale due to varying harvest arrangements. For example, fruits are not necessarily harvested when they are ideal for harvest, but when it is convenient. Observations of mature fruits on a tree basis (e.g., Navarro et al., 2008, on coconut) would be more suitable to compare with modeled yield, but such data are not available at our sites. Some studies have also demonstrated important physiological mechanisms on oil palm yield including inflorescence gender determination and abortion rates that both respond to seasonal climatic dynamics although with a time lag (Combres et al., 2013; Legros et al., 2009). The lack of representation of such physiological traits might affect the seasonal dynamics of yield simulated by our model, but these mechanisms are rarely considered in a land surface modeling context. Nevertheless, the results correspond generally to the purpose of our modeling, which is focused on the longterm climatological effects of oil palm agriculture. The correct representation of multi-year trend of $\mathrm{C}$ balance which we did reach is more important than the correct prediction of each yield. For the latter the more agriculturally oriented models should be used.

Resource allocation patterns for perennial crops are more difficult to simulate than annual crops. For annuals, the LAI is often assumed to decline during grain-fill (Levis et al., 2012). However, the oil palm has to sustain a rather stable leaf area while partitioning a significant amount of $\mathrm{C}$ to the fruits. The balance between reproductive and vegetative allocations is crucial. The dynamics of $A_{\text {fruit }}$ as a function of monthly NPP is proved useful to capture the increasing yield capacity of oil palms during maturing at favorable conditions (Figs. 6, 7) and also able to adjust fruit allocation and shift resources to the vegetative components under stress conditions (e.g., $\mathrm{N}$ limitation, Figs. 9 and 10). The value of $A_{\text {fruit }}$ in- 
creased from 0.5 to 1.5 (Fig. 3), resulting in more than a half partitioning of NPP to the reproductive pool at mature stage, which matched closely with field observations (Fig. 10; Kotowska et al., 2015a, b). Our experiments (not shown here) confirmed that the dynamic function is more robust than a simple time-dependent or vegetation-size-dependent allocation function.

The phenology and allocation processes in land surface models usually aim to represent the average growth trend of a PFT at large spatial scale (Bonan et al., 2002; Drewniak et al., 2013). We made a step forward by comparing point simulations with multiple specific site observations. The model predicts well the average LAI development and yield as well as NPP of mature plantations across two different regions. Site-to-site variability in yield and NPP at the Harapan and Bukit Duabelas plots under contrasting conditions (regular vs. reduced fertilization) is largely captured by the model. The decreasing trend of yield and pause of LAI growth in B plots after 10 years (Figs. 9, 10) reflect reduced $\mathrm{N}$ availability observed in the clay Acrisol soil in Bukit Duabelas (Allen et al., 2015) with very limited $\mathrm{C}$ and $\mathrm{N}$ return from leaf litter because of the pruning and piling of highly lignified leaves (Guillaume et al., 2015). Yet there remains smallscale discrepancy in LAI, NPP or yield in some sites, which is possibly due to the fact that microclimate, surface input data, and the amount and timing of fertilization were only prescribed as two categories for $\mathrm{H}$ and $\mathrm{P}$ plots, respectively. Field data show the proportion of NPP allocated to yield is significantly higher in plot $\mathrm{HO} 1(70 \%)$ than in other plots (50 to $65 \%$ ), which could explain the low LAI of HO1. This is not reflected in the model as the same parameters are used in the fruit allocation function (Eq. 5) across sites. The deviation in allocation pattern is likely due to differences in plantation management (e.g., harvest and pruning cycles), which has been shown to be crucial for determining vegetative and reproductive growth (Euler, 2015). Other factors such as insects, fungal infection and possibly different oil palm progenies could also result in difference in oil palm growth and productivity, but they are typically omitted in land surface models. Generalized input parameterization across a region is usually the case when modeling with a PFT, although a more complex management scheme (e.g., dynamic fertilization) could be devised and evaluated thoroughly with additional field data, which we lack at the moment.

Overall, the sub-canopy phytomer-based structure, the extended phenological phases for a perennial crop PFT and the two-step allocation scheme of CLM-Palm are distinct from existing functions in land surface models. The phytomer configuration is similar to the one already implemented in other oil palm growth and yield models such as the APSIM-Oil Palm model (Huth et al., 2014) or the ECOPALM yield prediction model (Combres et al., 2013). But the implementation of this sub-canopy structure is the first attempt among land surface models. CLM-Palm incorporates the ability of an agricultural model for simulating growth and yield, be- sides that it allows the modeling of biophysical and biogeochemical processes as a land model should do. For example, what is the whole fate of $\mathrm{C}$ in plant, soil and atmosphere if land surface composition shifts from a natural system to the managed oil palm system? In a following study, a fuller picture of the $\mathrm{C}, \mathrm{N}$, water and energy fluxes over the oil palm landscape is examined with CLM-Palm presented here and evaluated with eddy covariance flux observation data. We develop this palm sub-model in the CLM framework as it allows coupling with climate models so that the feedbacks of oil palm expansion to climate can be simulated in future steps.

\section{Conclusions}

The development of CLM-Palm including canopy structure, phenology, and $\mathrm{C}$ - and $\mathrm{N}$-allocation functions was proposed for modeling an important agricultural system in the tropics. This paper demonstrates the ability of the new palm module to simulate the inter-annual dynamics of vegetative growth and fruit yield from field planting to full maturity of the plantation. The sub-canopy-scale phenology and allocation strategy are necessary for this perennial evergreen crop which yields continuously on multiple phytomers. The preexpansion leaf storage growth phase is proved essential for buffering and balancing overall vegetative and reproductive growth. Average LAI, yield and NPP are satisfactorily simulated for multiple sites, which fulfills the main mission of a land surface modeling approach, that is, to represent the average conditions and dynamics of large-scale processes. On the other hand, simulating small-scale site-to-site variation $(50 \mathrm{~m} \times 50 \mathrm{~m}$ sites) requires detailed input data on site conditions (e.g., microclimate) and plantation managements that are often not available, thus limiting the applicability of the model at small scale. Nevertheless, the CLM-Palm model sufficiently represents the significant region-wide variability in oil palm NPP and yield driven by nutrient input and plantation age in Jambi, Sumatra. The point simulations here provide a starting point for calibration and validation at large scales.

To be run in a regional or global grid, the age class structure of plantations needs to be taken into account. This can be achieved by setting multiple replicates of the PFT for oil palm, each planted at a point of time at a certain grid. As a result, a series of oil palm cohorts developing at different grids could be configured with a transient PFT distribution data set, which allows for a quantitative analysis of the effects of land-use changes, specifically rainforest to oil palm conversion, on $\mathrm{C}$, water and energy fluxes. This will contribute to the land surface modeling community for simulating this structurally unique, economically and ecologically sensitive, and fast expanding oil palm land cover. 


\section{Appendix A: Summary of main parameters}

Table A1. Summary of new phenological parameters introduced for the phenology subroutine of CLM-Palm. The default values were determined by calibration and with reference to field observations and literature on oil palm (Combres et al., 2013; Corley and Tinker, 2003; Hormaza et al., 2012; Legros et al., 2009).

\begin{tabular}{|c|c|c|c|c|}
\hline Parameter & Default & Min & Max & Explanation (unit) \\
\hline GDD $_{\text {init }}$ & 0 & 0 & 1500 & $\begin{array}{l}\text { GDD needed from planting to the first phytomer initiation (degree days). Initiation refers to } \\
\text { the start of active accumulation of leaf } \mathrm{C} \text {. A value } 0 \text { implies transplanting. }\end{array}$ \\
\hline$G D_{\exp }$ & 1550 & 0 & 8000 & $\begin{array}{l}\text { GDD needed from leaf initiation to start of leaf expansion for each phytomer (pre- } \\
\text { expansion) (degree days) }\end{array}$ \\
\hline GDDL.mat & 1250 & 500 & 1600 & $\begin{array}{l}\text { GDD needed from start of leaf expansion to leaf maturity for each phytomer (post- } \\
\text { expansion) (degree days) }\end{array}$ \\
\hline $\mathrm{GDD}_{\text {F.fill }}$ & 3800 & 3500 & 4200 & $\begin{array}{l}\text { GDD needed from start of leaf expansion to beginning of fruit-fill for each phytomer (de- } \\
\text { gree days) }\end{array}$ \\
\hline GDDF.mat & 5200 & 4500 & 6500 & $\begin{array}{l}\text { GDD needed from start of leaf expansion to fruit maturity and harvest for each phytomer } \\
\text { (degree days) }\end{array}$ \\
\hline GDD $_{\text {L.sen }}$ & 6000 & 5000 & 8000 & $\begin{array}{l}\text { GDD needed from start of leaf expansion to beginning of senescence for each phytomer } \\
\text { (degree days) }\end{array}$ \\
\hline $\mathrm{GDD}_{\text {end }}$ & 6650 & 5600 & 9000 & $\begin{array}{l}\text { GDD needed from start of leaf expansion to end of senescence for each phytomer (de- } \\
\text { gree days) }\end{array}$ \\
\hline $\mathrm{GDD}_{\min }$ & 7500 & 6000 & 10000 & GDD needed from planting to the beginning of first fruit-fill (degree days) \\
\hline $\mathrm{Age}_{\max }$ & 25 & 20 & 30 & $\begin{array}{l}\text { Maximum plantation age (productive period) from planting to final rotation/replanting } \\
\text { (years) }\end{array}$ \\
\hline $\mathrm{PLAI}_{\max }$ & 0.165 & 0.1 & 0.2 & Maximum LAI of a single phytomer $\left(\mathrm{m}^{2} \mathrm{~m}^{-2}\right)$ \\
\hline mxlivenp & 40 & 30 & 50 & Maximum number of expanded phytomers coexisting on a palm \\
\hline phyllochron & 130 & 100 & 160 & $\begin{array}{l}\text { Initial phyllochron (i.e., plastochron): the period in heat unit between the initiations of two } \\
\text { successive phytomers. The value increases to } 1.5 \text { times, i.e., 195, at } 10 \text { years old (degree } \\
\text { days) }\end{array}$ \\
\hline
\end{tabular}

Table A2. Summary of parameters involved in $\mathrm{C}$ and $\mathrm{N}$ allocation. The default values were determined by calibration and with reference to field measurements (Kotowska et al., 2015a).

\begin{tabular}{|c|c|c|c|c|}
\hline Parameter & Defaults & Min & Max & Explanation (unit) \\
\hline * $1 f_{\text {disp }}$ & 0.3 & 0.1 & 1 & Fraction of $\mathrm{C}$ and $\mathrm{N}$ allocated to the displayed leaf pool \\
\hline *transplant & 0.15 & 0 & 0.3 & $\begin{array}{l}\text { Initial total LAI assigned to existing expanded phytomers at transplanting. Value } 0 \text { implies } \\
\text { planting as seeds. }\end{array}$ \\
\hline$f_{\text {leaf }}^{\mathrm{i}}$ & 0.15 & 0 & 1 & Initial value of leaf allocation coefficient before the first fruit-fill \\
\hline$a_{\text {root }}^{1}$ & 0.3 & 0 & 1 & Initial value of root allocation coefficient before the first fruit-fill \\
\hline$a_{\text {leaf }}^{\mathrm{f}}$ & 0.28 & 0 & 1 & Final value of leaf allocation coefficient after vegetative maturity \\
\hline$a_{\text {root }}^{f}$ & 0.1 & 0 & 1 & Final value of root allocation coefficient after vegetative maturity \\
\hline$F_{\text {stem }}^{\text {live }}$ & 0.15 & 0 & 1 & $\begin{array}{l}\text { Fraction of new stem allocation that goes to live stem tissues, the rest to metabolically } \\
\text { inactive stem tissues }\end{array}$ \\
\hline$d_{\text {mat }}$ & 0.6 & 0.1 & 1 & Factor to control the age when the leaf allocation ratio stabilizes at $a_{\text {leaf }}^{\mathrm{f}}$ according to Eq. (4) \\
\hline$d_{\text {alloc }}^{\text {leaf }}$ & 0.6 & 0 & 5 & $\begin{array}{l}\text { Factor to control the nonlinear function in Eq. (4). Values }<1 \text {, give a convex curve and } \\
\text { those }>1 \text { give a concave curve. Value } 1 \text { gives a linear function. }\end{array}$ \\
\hline$* a$ & 0.2 & 0 & 1 & Parameter $a$ for fruit allocation coefficient $A_{\text {fruit }}$ in Eq. (5) \\
\hline${ }^{*} b$ & 0.02 & 0 & 1 & Parameter $b$ for fruit allocation coefficient $A_{\text {fruit }}$ in Eq. (5) \\
\hline SLA & 0.013 & 0.01 & 0.015 & Specific leaf area $\left(\mathrm{m}^{2} \mathrm{~g}^{-1} \mathrm{C}\right)$ \\
\hline$F_{\text {LNR }}$ & 0.1005 & 0.05 & 0.1 & $\begin{array}{l}\text { Fraction of leaf } \mathrm{N} \text { in Rubisco enzyme. Used together with SLA to calculate } V_{\text {cmax } 25} \\
\left(\mathrm{~g} N \text { Rubiscog }{ }^{-1} \mathrm{~N}\right)\end{array}$ \\
\hline
\end{tabular}

* New parameters introduced for oil palm. Others are existing parameters in CLM but mostly are redefined or used in changed context. 
Table A3. Other optical, morphological, and physiological parameters for oil palm.

\begin{tabular}{|c|c|c|c|}
\hline Parameter & Value & Definition (unit) & Comments \\
\hline $\mathrm{CN}_{\text {leaf }}$ & 33 & Leaf $\mathrm{C}: \mathrm{N}$ ratio $\left(\mathrm{g} \mathrm{Cg}^{-1} \mathrm{~N}\right)$ & By leaf $\mathrm{C}: \mathrm{N}$ analysis \\
\hline $\mathrm{CN}_{\text {root }}$ & 42 & Root $\mathrm{C}: \mathrm{N}$ ratio $\left(\mathrm{g} \mathrm{Cg}^{-1} \mathrm{~N}\right)$ & Same as all other PFTs \\
\hline $\mathrm{CN}_{\text {livewd }}$ & 50 & Live stem $\mathrm{C}: \mathrm{N}$ ratio $\left(\mathrm{g} \mathrm{C} \mathrm{g}^{-1} \mathrm{~N}\right)$ & Same as all other PFTs \\
\hline $\mathrm{CN}_{\text {deadwd }}$ & 500 & Dead stem $\mathrm{C}: \mathrm{N}$ ratio $\left(\mathrm{g} \mathrm{C} \mathrm{g}^{-1} \mathrm{~N}\right)$ & Same as all other PFTs \\
\hline $\mathrm{CN}_{1 f l i t}$ & 60 & Leaf litter $\mathrm{C}: \mathrm{N}$ ratio $\left(\mathrm{g} \mathrm{C}^{-1} \mathrm{~N}\right)$ & Same as other tree PFTs \\
\hline $\mathrm{CN}_{\text {fruit }}$ & 75 & Fruit $\mathrm{C}: \mathrm{N}$ ratio $\left(\mathrm{g} \mathrm{Cg}^{-1} \mathrm{~N}\right)$ & $\begin{array}{l}\text { Higher than the value } 50 \text { for other crops be- } \\
\text { cause of high oil content in palm fruit }\end{array}$ \\
\hline$r_{\text {vis/nir }}^{\text {leaf }}$ & $0.09 / 0.45$ & $\begin{array}{l}\text { Leaf reflectance in the visible (VIS) or near- } \\
\text { infrared (NIR) bands }\end{array}$ & Values adjusted in between trees and crops \\
\hline$r_{\text {vis/nir }}^{\text {stem }}$ & $0.16 / 0.39$ & $\begin{array}{l}\text { Stem reflectance in the visible or near- } \\
\text { infrared bands }\end{array}$ & Values adjusted in between trees and crops \\
\hline$\tau_{\text {vis/nir }}^{\text {leaf }}$ & $0.05 / 0.25$ & $\begin{array}{l}\text { Leaf transmittance in the visible or near- } \\
\text { infrared bands }\end{array}$ & Values adjusted in between trees and crops \\
\hline$\tau_{\text {vis/nir }}^{\text {stem }}$ & $0.001 / 0.001$ & $\begin{array}{l}\text { Stem transmittance in the visible or near- } \\
\text { infrared bands }\end{array}$ & Values adjusted in between trees and crops \\
\hline$\chi_{\mathrm{L}}$ & -0.4 & $\begin{array}{l}\text { Leaf angle distribution index for radiative } \\
\text { transfer }(0=\text { random leaves; } 1=\text { horizontal } \\
\text { leaves; }-1=\text { vertical leaves })\end{array}$ & $\begin{array}{l}\text { Estimated by field observation. In CLM, } \\
-0.4 \leq \chi_{\mathrm{L}} \leq 0.6\end{array}$ \\
\hline taper & 50 & $\begin{array}{l}\text { Ratio of stem height to radius at breast } \\
\text { height }\end{array}$ & $\begin{array}{l}\text { Field observation. Used together with } \\
\text { stocking and dwood to calculate canopy top } \\
\text { and bottom heights. }\end{array}$ \\
\hline stocking & 150 & Number of palms per hectare (stems ha ${ }^{-2}$ ) & $\begin{array}{l}\text { Field observation. Used to calculate stem } \\
\text { area index (SAI) by: SAI }=0.05 \times \mathrm{LAI} \times \\
\text { stocking. }\end{array}$ \\
\hline dwood & 100000 & Wood density $\left(\mathrm{gC} \mathrm{m}^{-3}\right)$ & $\begin{array}{l}\text { Similar to coconut palm (O. Roupsard, per- } \\
\text { sonal communication, 2015) }\end{array}$ \\
\hline$R_{z 0 \mathrm{~m}}$ & 0.05 & $\begin{array}{l}\text { Ratio of momentum roughness length to } \\
\text { canopy top height }\end{array}$ & T. June (personal communication, 2014) \\
\hline$R_{\mathrm{d}}$ & 0.76 & $\begin{array}{l}\text { Ratio of displacement height to canopy top } \\
\text { height }\end{array}$ & T. June (personal communication, 2014) \\
\hline
\end{tabular}




\section{The Supplement related to this article is available online at doi:10.5194/gmd-8-3785-2015-supplement.}

Acknowledgements. This study was funded by the European Commission Erasmus Mundus FONASO Doctorate fellowship. Field trips were partly supported by the Collaborative Research Centre 990 (Ecological and Socioeconomic Functions of Tropical Lowland Rainforest Transformation Systems (Sumatra, Indonesia)) funded by the German Research Foundation (DFG). We are grateful to Kara Allen (University of Göttingen, Germany), Bambang Irawan (University of Jambi, Indonesia) and the PTPN-VI plantation in Jambi for providing field data on oil palm. The source code of the post-4.5 version CLM model was provided by Samuel Levis from National Center for Atmospheric Research (NCAR), Boulder, CO, USA. We also thank three anonymous reviewers for their constructive comments during the open discussion and revision phases.

This open-access publication was funded by the University of Göttingen.

Edited by: M.-H. Lo

\section{References}

Allen, K., Corre, M. D., Tjoa, A., and Veldkamp, E.: Soil nitrogencycling responses to conversion of lowland forests to oil palm and rubber plantations in Sumatra, Indonesia, PLoS ONE, 10, e0133325, doi:10.1371/journal.pone.0133325, 2015.

Bonan, G. B., Levis, S., Kergoat, L., and Oleson, K. W.: Landscapes as patches of plant functional types: An integrated concept for climate and ecosystem models, Global Biogeochem. Cy., 16, 1021-1051, 2002.

Carlson, K. M., Curran, L. M., Asner, G. P., Pittman, A. M., Trigg, S. N., and Adeney, J. M.: Carbon emissions from forest conversion by Kalimantan oil palm plantations, Nature Clim. Change, 3, 283-287, doi:10.1038/nclimate1702, 2012.

Carrasco, L. R., Larrosa, C., Milner-Gulland, E. J., and Edwards, D. P.: A double-edged sword for tropical forests, Science, 346, 38-40, 2014.

Combres, J.-C., Pallas, B., Rouan, L., Mialet-Serra, I., Caliman, J.-P., Braconnier, S., Soulie, J.-C., and Dingkuhn, M.: Simulation of inflorescence dynamics in oil palm and estimation of environment-sensitive phenological phases: a model based analysis, Funct. Plant Biol., 40, 263-279, 2013.

Corley, R. H. V. and Tinker, P. B. (Eds.): The oil palm, 4th Edn., Blackwell Science, Oxford, 2003.

Dee, D. P., Uppala, S. M., Simmons, A. J., Berrisford, P., Poli, P., Kobayashi, S., Andrae, U., Bidlot, J., Bormann, N., Delsol, C., Dragani, R., Fuentes, M., Geer, A. J., Haimberger, L., Healy, S. B., Hersbach, H., Hólm, E. V., Isaksen, L., Kållberg, P., Köhler, M., Matricardi, M., McNally, A. P., Monge-Sanz, B. M., Morcrette, J.-J., Park, B.-K., Peubey, C., de Rosnay, P., Tavolato, C., Thépaut, J.-N., and Vitart, F. : The ERA-Interim reanalysis: Configuration and performance of the data assimilation system, Q. J Roy. Meteor. Soc., 137, 553-597, 2011.
Drewniak, B., Song, J., Prell, J., Kotamarthi, V. R., and Jacob, R.: Modeling agriculture in the Community Land Model, Geosci Model Dev., 6, 495-515, doi:10.5194/gmd-6-495-2013, 2013.

Euler, M.: Oil palm expansion among Indonesian smallholders adoption, welfare implications and agronomic challenges, $\mathrm{PhD}$ thesis, University of Göttingen, Germany, 145 pp., 2015.

FAO: FAOSTAT Database, Food and Agriculture Organization of the United Nations, Rome, Italy, available at: http://faostat.fao. org/site/339/default.aspx (last access: 31 October 2015), 2013.

Fisher, J. B., Huntzinger, D. N., Schwalm, C. R., and Sitch, S.: Modeling the terrestrial biosphere, Annu. Rev. Environ. Resour., 39, 91-123, doi:10.1146/annurev-environ-012913-093456, 2014.

Galloway, J. N., Dentener, F. J., Capone, D. G., Boyer, E. W., Howarth, R. W., Seitzinger, S. P., Asner, G. P., Cleveland, C. C., Green, P. A., Holland, E. A., Karl, D. M., Michaels, A. F., Porter, J. H., Townsend, A. R., and Vörösmarty, C. J.: Nitrogen cycles: past, present, and future, Biogeochemistry, 70, 153-226, 2004.

Georgescu, M., Lobell, D. B., and Field, C. B.: Direct climate effects of perennial bioenergy crops in the United States, P. Natl. Acad. Sci., 108, 4307-4312, 2011.

Goh, K. J.: Climatic requirements of the oil palm for high yields, in: Managing oil palm for high yields: agronomic principles, edited by: Goh, K. J., 1-17, Malaysian Soc. Soil Sci. and Param Agric. Surveys, Kuala Lumpur, 2000.

Guillaume, T., Damris, M., and Kuzyakov, Y.: Losses of soil carbon by converting tropical forest to plantations: erosion and decomposition estimated by $\delta^{13} \mathrm{C}$, Glob. Change Biol., 21, 3548-3560, doi:10.1111/gcb.12907, 2015.

Gunarso, P., Hartoyo, M. E., Agus, F., and Killeen, T. J.: Oil palm and land use change in Indonesia, Malaysia, and Papua New Guinea, in: Reports from the Technical Panels of the 2nd Greenhouse Gas Working Group of the Roundtable on Sustainable Palm Oil (RSPO), edited by: Killeen, T. and Goon, J., RSPO, Kuala Lumpur, 2013.

Hallé, F., Oldeman, R. A. A., and Tomlinson, P. B.: Tropical trees and forests. An architectural analysis, Springer-Verlag, Berlin, 441 pp., 1978.

Hijmans, R. J., Cameron, S. E., Parra, J. L., Jones, P. G., and Jarvis, A.: Very high resolution interpolated climate surfaces for global land areas, Int. J. Climatol., 25, 1965-1978, 2005.

Hoffmann, M. P., Vera, A. C., Van Wijk, M. T., Giller, K. E., Oberthür, T., Donough, C., and Whitbread, A. M.: Simulating potential growth and yield of oil palm (Elaeis guineensis) with PALMSIM: Model description, evaluation and application, Agr. Syst., 131, 1-10, 2014.

Hormaza, P., Fuquen, E. M., and Romero, H. M.: Phenology of the oil palm interspecific hybrid Elaeis oleifera $\times$ Elaeis guineensis, Sci. Agr., 69, 275-280, 2012.

Huth, N. I., Banabas, M., Nelson, P. N., and Webb, M.: Development of an oil palm cropping systems model: lessons learned and future directions, Environ. Modell. Softw., 62, 411-419, doi:10.1016/j.envsoft.2014.06.021, 2014.

Jin, J. M. and Miller, N. L.: Regional simulations to quantify land use change and irrigation impacts on hydroclimate in the California Central Valley, Theor. Appl. Climatol., 104, 429-442, 2011.

Koh, L. P. and Ghazoul, J.: Spatially explicit scenario analysis for reconciling agricultural expansion, forest protection, and carbon conservation in Indonesia, P. Natl. Acad. Sci. USA, 107, 11140 11144, doi:10.1073/pnas.1000530107, 2010. 
Kotowska, M. M., Leuschner, C., Triadiati T., Selis M., and Hertel, D.: Quantifying above- and belowground biomass carbon loss with forest conversion in tropical lowlands of Sumatra (Indonesia), Global Change Biol., 21, 3620-3634, doi:10.1111/gcb.12979, 2015a.

Kotowska, M. M., Leuschner, C., Triadiati, T., and Hertel, D.: Conversion of tropical lowland forest reduces nutrient return through litterfall, and alters nutrient use efficiency and seasonality of net primary production, Oecologia, doi:10.1007/s00442-015-34815 , in press, 2015 b.

Koven, C. D., Riley, W. J., Subin, Z. M., Tang, J. Y., Torn, M. S., Collins, W. D., Bonan, G. B., Lawrence, D. M., and Swenson, S. C.: The effect of vertically resolved soil biogeochemistry and alternate soil $\mathrm{C}$ and $\mathrm{N}$ models on C dynamics of CLM4, Biogeosciences, 10, 7109-7131, doi:10.5194/bg-10-7109-2013, 2013.

Legros, S., Mialet-Serra, I., Caliman, J. P., Siregar, F. A., ClementVidal A., and Dingkuhn, M.: Phenology and growth adjustments of oil palm (Elaeis guineensis) to photoperiod and climate variability, Ann. Bot., 104, 1171-1182, doi:10.1093/aob/mcp214, 2009.

Levis, S., Bonan, G., Kluzek, E., Thornton, P., Jones, A., Sacks, W., and Kucharik, C.: Interactive crop management in the Community Earth System Model (CESM1): Seasonal influences on land-atmosphere fluxes, J. Climate, 25, 4839-4859, doi:10.1175/JCLI-D-11-00446.1, 2012.

Luyssaert, S., Schulze, E. D., Börner, A., Knohl, A., Hessenmöller, D., Law, B. E., Ciais, P., and Grace, J.: Old-growth forests as global carbon sinks, Nature, 455, 213-215, 2008.

Miettinen, J., Shi, C. H., and Liew, S. C.: Deforestation rates in insular Southeast Asia between 2000 and 2010, Glob. Change Biol., 17, 2261-2270, 2011.

Navarro, M. N. V., Jourdan, C., Sileye, T., Braconnier, S., MialetSerra, I., Saint-Andre, L., Dauzat, J., Nouvellon, Y., Epron, D., Bonnefond, J. M., Berbigier, P., Rouziere, A., Bouillet, J. P., and Roupsard, O.: Fruit development, not GPP, drives seasonal variation in NPP in a tropical palm plantation, Tree Physiol., 28, 1661-1674, 2008.
Oleson, K., Lawrence, D., Bonan, G., Drewniak, B., Huang, M., Koven, C., Levis, S., Li, F., Riley, W., Subin, Z., Swenson, S., Thornton, P., Bozbiyik, A., Fisher, R., Heald, C., Kluzek, E., Lamarque, J.-F., Lawrence, P., Leung, L., Lipscomb, W., Muszala, S., Ricciuto, D., Sacks, W., Sun, Y., Tang, J., and Yang, Z.-L.: Technical description of version 4.5 of the Community Land Model (CLM), National Center for Atmospheric Research, Boulder, Colorado, USA, 420 pp., doi:10.5065/D6RR1W7M, 2013.

Oleson, K. W., Bonan, G. B., Levis, S., and Vertenstein, M.: Effects of land use change on North American climate: impact of surface datasets and model biogeophysics, Clim. Dynam., 23, 117-132, 2004.

Tang, J. Y., Riley, W. J., Koven, C. D., and Subin, Z. M.: CLM4BeTR, a generic biogeochemical transport and reaction module for CLM4: model development, evaluation, and application, Geosci. Model Dev., 6, 127-140, doi:10.5194/gmd-6-127-2013, 2013.

van Kraalingen, D. W. G., Breure, C. J., and Spitters, C. J. T.: Simulation of oil palm growth and yield, Agricultural and forest meteorology, 46(3), 227-244, 1989.

Veldkamp, E. and Keller, M.: Nitrogen oxide emissions from a banana plantation in the humid tropics, J. Geophys. Res.-Atmos., 102, 15889-15898, 1997.

White, M. A., Thornton, P. E., and Running, S. W.: A continental phenology model for monitoring vegetation responses to interannual climatic variability, Global Biogeochem. Cy., 11, 217-234, 1997. 